\title{
Platinum, palladium, and rhodium in airborne particulate matter
}

\author{
Jasmina Rinkovec \\ Institute for Medical Research and Occupational Health, Environmental Hygiene Unit, Zagreb, Croatia
}

[Received in May 2019; Similarity Check in May 2019; Accepted in September 2019]

\begin{abstract}
Measurable quantities of platinum, palladium, and rhodium, even in remote areas of the planet, evidence the global nature of pollution with these metals, mostly from catalytic converters of modern vehicles (other sources are jewellery production, chemical industry, and anticancer drugs). The amount of the platinum group metals (PGMs) emitted from automobile catalysts varies with the type, age, and condition of the engine and the catalyst, as well as the style of driving. Current literature suggests that the concentrations of these metals have increased considerably over the last twenty years, palladium concentrations in particular, as it has been proved more effective catalyst than platinum. However, whether and to what extent the emitted PGMs are toxic for people is still a controversy. The potential health risk from exposure to these elements is most likely for those living in urban environments with busy roads or along major highways. Because of the importance of PGMs and their trace levels in particulate matter, sensitive methods are required for reliable determination. This review discusses particular steps of analytical procedures for PGM quantification in airborne particulate matter and addresses the common preparation, detection, and determination methods.
\end{abstract}

KEY WORDS: automotive catalytic converter; ICP-MS; microwave digestion; platinum group metals; spectral interferences

Along with osmium (Os), iridium (Ir), and ruthenium $(\mathrm{Ru})$, platinum $(\mathrm{Pt})$, palladium $(\mathrm{Pd})$, and rhodium $(\mathrm{Rh})$ are transitional metals of the periodic system of elements that belong to the platinum group. Platinum was brought to Europe in 1735 from today's Colombia and was described in literature in 1748. English chemist W. H. Wollaston, who devoted his work to the study of natural platinum noted that there were metals of very similar nature to crude platinum. In 1803, he discovered palladium and rhodium. In 1804, S. Tennant, a friend of Wollaston's, discovered two more platinum group metals (PGMs): osmium and iridium. Osann, a chemistry professor, found a new residual element in natural platinum and called it ruthenium (Latin name for Russia). His former teacher Berzelius, however, expressed doubts, and Osann retracted his discovery. In 1844, a Russian chemist Klaus confirmed Osann's discovery of rhutenium in a larger sample of insoluble natural platinum residue (1).

Platinum, palladium, and rhodium are rare in the Earth's crust, with estimated concentrations of $0.06-0.4 \mu \mathrm{g} / \mathrm{kg}$ (2).

Platinum and its alloys are used in the glass industry to obtain very clean glass. Platinum is also used as a catalyst in many reactions such as hydrogenation, dehydrogenation, isomerisation, dehydration, cyclisation, oxidation (e.g. ammonia in nitric acid) (3). It is also used as a catalyst in reactions that increase the octane number of gasoline and various other fuels. Except as a combustion catalyst,

Corresponding author: Jasmina Rinkovec, Institute for Medical Research and Occupational Health, Environmental Hygiene Unit, Ksaverska cesta 2, Zagreb, Croatia, E-mail: jrinkovec@imi.hr platinum is also used as a catalytic converter for the removal of incomplete combustion residues in automotive exhaust systems. Large amounts of platinum are used in dentistry and the production of various medical tools and laboratory equipment (such as pots, pans, and tweezers). It is also used for making jewellery (3).

Palladium too has a widespread application. It is also used for electrical contacts, especially in telephones. Its alloys are used to produce resistant wire ( $\mathrm{Pd}-\mathrm{Ag})$, thermocouples (Pd-Pt-Au), jewellery (Pd-Ru-Rh), and dental casts (4).

Rhodium is mainly used as an alloying addition of platinum and palladium, because it increases their hardness. Such alloys are used as shells of high temperature gas and electric laboratory furnaces and for welding electrodes in space technology. Due to corrosion resistance, good conductivity, and low transitional resistance, they are also used for making electrical contacts and switches. Rhodium alloys are also used by goldsmiths. Elementary rhodium is used for electroplating mirrors for various optical devices, because it gives a very hard and highly reflective layer. Rhodium powder is toxic and its soluble salts even more so. The maximum levels of rhodium and its salts in production plants are $0.1 \mathrm{mg} / \mathrm{m}^{3}$ and $0.001 \mathrm{mg} / \mathrm{m}^{3}$ respectively (4).

\section{AUTOMOTIVE CATALYTIC CONVERTERS}

The first automobile Pt-Pd catalytic converters from the 1970 s gradually evolved to also utilise $\mathrm{Rh}(5,6)$. These 
three-way converters consist of a metal box with a cordierite ceramic honeycomb coated with $\mathrm{Pt}, \mathrm{Pd}$ and/or Rh (Figure 1) (7). Earlier two-way catalytic converters were called oxidation catalysts, as they oxidised carbon(II) oxide and hydrocarbons (unburnt and/or partly burnt fuel) into carbon(IV) oxide and water. They are still used in diesel engines.

Three-way catalytic converters, in turn, can also reduce oxides (NOx, $\mathrm{x}=1,2)$ to elementary nitrogen and oxygen (8), as follows:

$$
\begin{aligned}
& 2 \mathrm{NO} \rightarrow \mathrm{N}_{2}+\mathrm{O}_{2} \\
& 2 \mathrm{NO}_{2} \rightarrow \mathrm{N}_{2}+2 \mathrm{O}_{2} \\
& 2 \mathrm{CO}+\mathrm{O}_{2} \rightarrow 2 \mathrm{CO}_{2} \\
& \mathrm{C}_{\mathrm{n}} \mathrm{H}_{2 n}+\frac{3 n}{2} \mathrm{O}_{2} \rightarrow \mathrm{nCO}_{2}+\mathrm{nH}_{2} \mathrm{O}
\end{aligned}
$$

For these processes to take place the operating temperature should be $300-800{ }^{\circ} \mathrm{C}$. Hot toxic fumes from the engine pass through the honeycomb containing the catalyst layer, which reduces the activation energy and increases the speed of chemical reactions. However, catalysts wear out with time and enter the environment along with exhaust gases.

This emission of nanocrystalline PGM particles depends to a large extent on engine operating conditions, age and type of catalytic converter, $\mathrm{PGM}$ content, $\mathrm{pH}$, and the type of fuel additive (9). PGM emissions can increase in unfavourable operational conditions like misfiring or excessive heating, which can destroy the converter. The emission mechanism and the form PGM takes in automobile exhaust are still unclear, but it is generally believed that the major cause is mechanical erosion of the converter surface.
Mitra and Sen (10) suggest that more than $50 \%$ of global $\mathrm{Pt}, \mathrm{Pd}$, and $\mathrm{Rh}$ is released through automobile catalytic converters. Other important anthropogenic sources are mining and fossil fuel burning.

\section{PARTICULATE MATTER AND PGMs}

Released $\mathrm{Pt}, \mathrm{Pd}$, and $\mathrm{Rh}$ attach to particulate matter $(\mathrm{PM})$, which is a mixture of various organic and inorganic compounds (metals, organic compounds, ions, adsorbed gases, and carbon) suspended in the air. They vary in shape, size, density, and origin (natural and anthropogenic). Physical and chemical properties of PM affect their behaviour in the air, deposition, distribution, and transport (11). Primary particles are those emitted directly from the source, while secondary particles are generated in the atmosphere from gaseous precursors such as sulphur(IV) oxide $\left(\mathrm{SO}_{2}\right)$, nitrogen(IV) oxide $\left(\mathrm{NO}_{2}\right)$, ammonia $\left(\mathrm{NH}_{3}\right)$, and volatile organic compounds (VOC). Particulate matter is classified into fractions based on equivalent aerodynamic diameter, which is the diameter of a sphere with density of $1 \mathrm{~g} / \mathrm{cm}^{3}$. The $\mathrm{PM}_{10}$ fraction is a thoracic or inhalable fraction that includes all PM with aerodynamic diameter lower than $10 \mu \mathrm{m}$. The $\mathrm{PM}_{2.5}$ fraction is called respirable and has aerodynamic diameter lower than $2.5 \mu \mathrm{m}$, whereas the $\mathrm{PM}_{1}$ fraction includes all particles of aerodynamic diameter lower than $1 \mu \mathrm{m}$ and can reach as deep into the lung as the alveoli $(11,12)$.

These PM fractions are often monitored for adverse effects on human health and are primarily associated with heart and lung diseases $(13,14)$. PGMs from catalytic converters are released into the environment as finely dispersed nanoparticles or washcoat particles $(15,16)$.

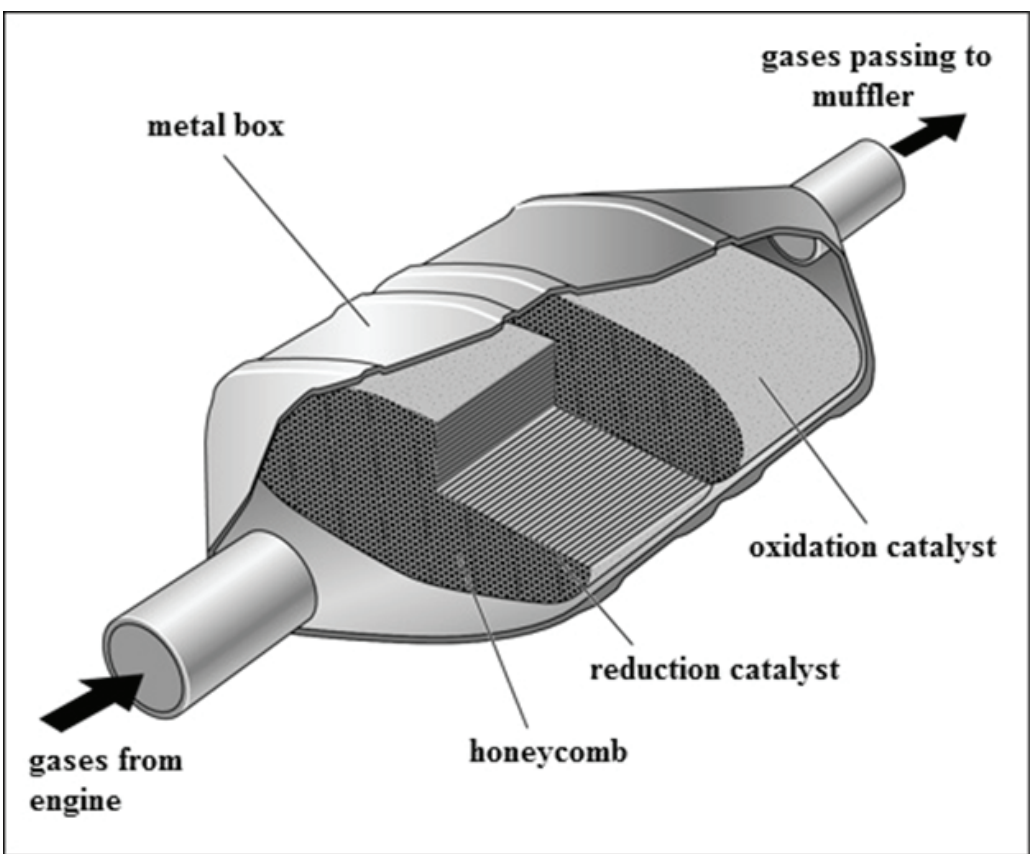

Figure 1 Parts of the automotive catalytic converter (adapted from https://www.dummies.com/wp-content/uploads/130970.image0.jpg) 


\section{METHODS FOR DETERMINING PGMs IN PM}

Determination of PGMs requires analytical methods of high sensitivity and selectivity, especially if they need to be quantified. Quantification most often relies on atomic absorption spectrometry (AAS) (17-19), atomic emission spectrometry (AES) $(19,20)$, and mass spectrometry (MS) (21-34). Samples analysed by these methods must be in liquid state. Therefore, the key step is their preparation and efficient digestion.

\section{Particulate matter sampling}

Samples of particulate matter are collected by passing a known volume of air through various types of filters such as membrane, quartz, Teflon, and glass fibre. There are two types of sampling devices: high volume samplers (HVS) and low volume samplers (LVS) $(35,36)$. Depending on the type used and fractions of particulate matter collected, sampling time can vary from a few hours to a week.

\section{Preparation of PM samples containing PGMs}

Filters with collected samples of particulate matter are digested with acids by microwave-assisted digestion (at high pressure and temperature) or thermal digestion. Various acids or acid mixtures and various high pressure instruments are used for digestion of samples. For example, Zereini et al. (22) report adding aqua regia and the standard of a selected metal isotope (high percentage of purity) to samples to accelerate preparation and in order to accelerate the preparation time, they used microwave digestion. When aqua regia is evaporated nearly to dryness hydrofluoric acid is added and then nitric acid is added several times to fully eliminate fluoride. Other authors have also reported using this preparation method to determine PGMs in particulate matter $(21,29,30)$. Other authors $(15,16,31)$, in turn, report using the NiS fire assay with isotope dilution. Rinkovec et al. (28) report using high temperature and pressure microwave digestion system with acid digestion for $\mathrm{PM}_{10}$ samples.

\section{Instrumental methods for determining PGMs in the environment}

The most common method for determining PGMs in particulate matter is inductively coupled plasma mass spectrometry (ICP-MS). However, it is quite demanding due to spectral interferences from the matrix, which is rather complex (see Table 1 for interferences for Pt, Pd and Rh). In order to remove them, samples are often prepared using methods of isotope dilution and various types of purification (cationic and anion exchange). Sometimes they can be removed with special mathematical equations, such as the one reported by Gómez et al. (37). Molecular interferences can also be efficiently removed by collision or dynamic reaction gases $(29,38,39)$. Bozlaker et al (40) reported using a dynamic reaction cell (DRC-q-ICP-MS) to detect metals in the $\mathrm{PM}_{10}$ and $\mathrm{PM}_{2.5}$ fractions collected in an underwater tunnel with two traffic lanes. Zereini et al. (22) used isotopic dilution (ID-ICP-Q-MS) for more accurate quantification of Pt, Pd, and Rh. Other authors $(15,21,27)$, in turn, used sector field SF-ICP-MS in high resolution mode. Among them, Hays et al. (27) reported detection limits of $0.01-2 \mu \mathrm{g} / \mathrm{m}^{3}$ but did not specify to which type of filter they applied. Pan et al. (23) reported ICP-MS detection limits for $\mathrm{Pt}, \mathrm{Pd}$, and $\mathrm{Rh}$ on quartz filters of $3.49 \mathrm{pg} / \mathrm{m}^{3}$, $60.6 \mathrm{pg} / \mathrm{m}^{3}$ and $0.44 \mathrm{pg} / \mathrm{m}^{3}$, respectively, explaining the high $\mathrm{Pd}$ detection limit with filter contamination with $\mathrm{Zn}$, which may generate additional spectral interference with chlorides in solution $\left({ }^{70} \mathrm{Zn}^{35} \mathrm{Cl},{ }^{68} \mathrm{Zn}^{37} \mathrm{Cl}\right)$. A similar explanation was proposed by Rinkovec et al. (28) for Pt, Pd, and Rh limits of detection on quartz, cellulose nitrate membrane, and glass fibre filters.

\section{LEVELS OF PGMs IN THE AIR}

Table 2 lists average mass concentrations of $\mathrm{Pt}, \mathrm{Pd}$, and $\mathrm{Rh}$ in particulate matter reported across the world. Most of these studies focused on the $\mathrm{PM}_{10}$ fraction and to a smaller degree on the $\mathrm{PM}_{2.5}$ fraction in cities with high traffic density such as Gothenburg, Sweden (37, 41), Rome, Italy (42), Mexico City, Mexico (15, 30), Buenos Aires, Argentina (43), Vienna, Austria (21), Houston (40) and Raleigh (27), USA, Zagreb, Croatia (32), Frankfurt, Germany (22, 44, $45)$, and Beijing $(23,29)$, Guangzhou (23), and Xinjiang (33), China. Only one focused on rural locations in Germany (Deuselbach, Neuglobsow) (22).

In Germany, annual mass concentrations (averaged for 2008 and 2009) in the $\mathrm{PM}_{10}$ fraction in Frankfurt were significantly higher than at the rural station in Neuglobsow. Yet, even though mass concentrations are lower in rural

Table 1 Spectral interferences for Rh, Pd, and Pt $(34,35)$

\begin{tabular}{lccc}
\hline Isotope & Abundance (\%) & Interference & Abundance (\%) \\
\hline \multirow{3}{*}{${ }^{103} \mathrm{Rh}$} & \multirow{3}{*}{100} & ${ }^{87} \mathrm{Rb}^{16} \mathrm{O}$ & 27.91 \\
\cline { 3 - 4 } & & ${ }^{206} \mathrm{~Pb}^{2+}$ & 24.10 \\
\cline { 3 - 4 } & \multirow{3}{*}{11.14} & ${ }^{63} \mathrm{Cu}^{40} \mathrm{Ar}$ & 68.91 \\
\cline { 3 - 4 } & & ${ }^{68} \mathrm{Zn}^{35} \mathrm{Cl}$ & 21.00 \\
\cline { 3 - 4 } & & ${ }^{40} \mathrm{Ar}{ }^{65} \mathrm{Cu}$ & 30.71 \\
\cline { 3 - 4 } & & ${ }^{88} \mathrm{Sr}^{16} \mathrm{O}^{1} \mathrm{H}$ & 82.37 \\
\hline${ }^{195} \mathrm{Pt}$ & 33.80 & ${ }^{89} \mathrm{Y}^{16} \mathrm{O}$ & 13.64 \\
\hline
\end{tabular}


Table 2 PGM mass concentrations in particulate matter in cities around the world

\begin{tabular}{|c|c|c|c|c|c|c|c|}
\hline City, country & $\begin{array}{c}\text { Sampling } \\
\text { period }\end{array}$ & Location & Fraction & $\begin{array}{c}\gamma(\mathbf{P t}) \\
\left(\mathrm{pg} / \mathbf{m}^{3}\right)\end{array}$ & $\begin{array}{c}\gamma(\mathbf{P d}) \\
\left(\mathbf{p g} / \mathbf{m}^{3}\right)\end{array}$ & $\begin{array}{c}\gamma(\mathbf{R h}) \\
\left(\mathbf{p g} / \mathbf{m}^{3}\right)\end{array}$ & Ref. \\
\hline Frankfurt, Germany & $1988-1998$ & roadside & $\mathrm{PM}_{10}$ & $0.9-246$ & & $0.2-15$ & (44) \\
\hline Rome, Italy & $1998 / 1999$ & urban & $\mathrm{PM}_{10}$ & 15.5 & 56.7 & 3.1 & $(42)$ \\
\hline \multirow{4}{*}{ Gothenburg, Sweden } & \multirow{4}{*}{1999} & \multirow{2}{*}{ high traffic } & $\mathrm{PM}_{10}$ & 14.1 & 4.9 & 2.9 & \multirow{4}{*}{$(41)$} \\
\hline & & & $\mathrm{PM}_{2.5}$ & 5.4 & 1.5 & 1.6 & \\
\hline & & \multirow{2}{*}{ low traffic } & $\mathrm{PM}_{10}$ & 2.1 & 1.8 & 0.6 & \\
\hline & & & $\mathrm{PM}_{2.5}$ & 2.7 & 1.4 & 0.5 & \\
\hline \multirow{2}{*}{ Rome, Italy } & \multirow{6}{*}{$1999 / 2000$} & downtown & \multirow{2}{*}{$\mathrm{PM}_{10}$} & 8.1 & 42.7 & 2.2 & \multirow{6}{*}{$(37)$} \\
\hline & & ring-road & & 8.6 & 54.9 & 3.0 & \\
\hline \multirow{2}{*}{ Gothenburg, Sweden } & & downtown & \multirow{2}{*}{$\mathrm{PM}_{10}$} & 13.1 & 4.6 & 2.7 & \\
\hline & & ring-road & & 4.1 & 1.6 & 0.8 & \\
\hline \multirow{2}{*}{ Madrid, Spain } & & downtown & \multirow{2}{*}{$\mathrm{PM}_{10}$} & 7.3 & & 2.8 & \\
\hline & & ring-road & & 17.7 & & 4.6 & \\
\hline $\begin{array}{l}\text { Buenos Aires, } \\
\text { Argentina }\end{array}$ & Mar 2001 & urban, traffic & $\mathrm{PM}_{10}$ & $2.3-47.7$ & & $0.3-16.8$ & $(43)$ \\
\hline \multirow{3}{*}{ Frankfurt, Germany } & \multirow{3}{*}{$2001 / 2002$} & main street & \multirow{3}{*}{$\mathrm{PM}_{10}$} & 23 & 15 & 4 & \multirow{3}{*}{$(45)$} \\
\hline & & side street & & 6 & 6 & 1 & \\
\hline & & rural area & & 5 & 3 & 1 & \\
\hline \multirow{2}{*}{ Boston, USA } & \multirow{2}{*}{$2002 / 2003$} & main street & \multirow{2}{*}{$\mathrm{PM}_{10}$} & 9.4 & 11.0 & 2.2 & \multirow{2}{*}{ (16) } \\
\hline & & side street & & 6.2 & 7.1 & 1.3 & \\
\hline Mexico City, Mexico & 2003 & urban traffic & $\mathrm{PM}_{10}$ & 9.3 & 11.0 & 3.2 & $(15)$ \\
\hline Raleigh, USA & Oct - Dec 2006 & near highway & $\mathrm{PM}_{10}$ & 20.0 & 29.0 & 1.0 & (27) \\
\hline Beijing, China & \multirow{2}{*}{ Oct - Dec 2007} & urban, traffic & $\mathrm{PM}_{10}$ & $6.22-24.3$ & & $1.16-8.60$ & \multirow{2}{*}{ (23) } \\
\hline Guangzhou, China & & urban, traffic & $\mathrm{PM}_{10}$ & $7.68-12.2$ & & $2.15-5.15$ & \\
\hline \multirow{2}{*}{ Frankfurt, Germany } & \multirow{4}{*}{$2008 / 2009$} & roadside, & $\mathrm{PM}_{10}$ & 12.4 & 43.9 & 3.2 & \\
\hline & & urban, traffic & $\mathrm{PM}_{2.5}$ & 9.4 & 16.1 & 1.8 & $(22)$ \\
\hline Deuselbach, Germany & & rural area & & 2.0 & 2.1 & 1.2 & $(22)$ \\
\hline Neuglobsow, Germany & & rural area & $\mathrm{PM}_{10}$ & 1.9 & 2.6 & 0.3 & \\
\hline & & & $\mathrm{PM}_{10}$ & 9.9 & 10.6 & & \\
\hline Vienna, Austrıa & $2009-2011$ & main street & $\mathrm{PM}_{2.5}$ & 2.3 & 4.9 & & $(21)$ \\
\hline Mexico City, Mexico & 2011 & urban traffic & $\mathrm{PM}_{2.5}$ & 45.8 & & & $(30)$ \\
\hline & & fan room & $\mathrm{PM}_{10}$ & 15.1 & 23.1 & 3.8 & \\
\hline Houston USA & Nov 2012 - Jan & ambient air & $\mathrm{PM}_{2.5}$ & 4.5 & 11.1 & 1.5 & $(40)$ \\
\hline Houston, USA & 2013 & tunnel & $\mathrm{PM}_{10}$ & 61.1 & 214.4 & 36.3 & $(40)$ \\
\hline & & ambient air & $\mathrm{PM}_{2.5}$ & 30.1 & 91.1 & 12.5 & \\
\hline & & background & & 0.49 & 3.86 & 0.44 & \\
\hline Zagreb, Croatia & $\begin{array}{c}\text { Apr } 2015 \text { - Mar } \\
2017\end{array}$ & low traffic & $\mathrm{PM}_{10}$ & 0.93 & 5.4 & 0.64 & $(32)$ \\
\hline & & high traffic & & 1.05 & 5.6 & 0.75 & \\
\hline Beijing, China & Oct - Nov 2014 & high traffic & $\mathrm{PM}_{2.5}$ & 9.35 & 76.92 & 1.31 & $(29)$ \\
\hline Kolka & Dec 2013 - Jan & traffic & $\mathrm{PM}_{10}$ & $6.27 *$ & $10.8^{*}$ & $0.70 *$ & $(46)$ \\
\hline Kolkata, Ind1a & 2014 & junction & $\mathrm{PM}_{2.5}$ & $6.45^{*}$ & $9.79 *$ & $0.62 *$ & $(46)$ \\
\hline
\end{tabular}

$*_{\text {values are shown in } \mathrm{ng} / \mathrm{m}^{3}}$ 
areas, they are still measurable, which suggests that PGMs can cross great(er) distances. A case in point is the finding of PGMs at higher altitudes, far from high-traffic roads in Greenland and Alps (34).

To my knowledge, the highest PGM concentrations, however, were measured at road junctions of Kolkata, India by Diong et al. (46). These were 10 to 1,000 times higher than in other parts of the world and confirmed road junctions as sites with the highest exposure but also pointed to industrial emissions as no lesser environmental polluters.

The study of Rinkovec et al. (32), carried out in Zagreb, Croatia was the first to report airborne PGM measurements in Southeast Europe. Palladium had the highest and Rh the lowest means. The ratio of measured mass concentrations at all monitoring stations was similar to the $\mathrm{Pt}, \mathrm{Pd}$, and $\mathrm{Rh}$ content in automobile catalytic converters (47). Mass concentrations of $\mathrm{Pt}, \mathrm{Pd}$, and $\mathrm{Rh}$ varied significantly with seasons, peaking in the winter, which was explained by more intense traffic and adverse weather conditions that slow down air exchange, so pollution stays lower to the ground.

The behaviour and bioavailability of PGMs in the environment imply higher health risks, as they can be transformed into toxic compounds once they enter the organism. There are reports of the formation of chloric complexes with $\mathrm{Pt}, \mathrm{Pd}$, and $\mathrm{Rh}$ in the lungs that can be seriously damaging $(15,30)$. Zereini et al. (49) and Wiseman et al. (50) investigated the mobility of PGMs using simulated lung fluids and showed that significant fractions of PGMs are physically and chemically bioaccessible in the human lung, which is important because of known toxicological and allergenic effects of soluble forms of PGMs.

\section{TOXICITY OF PLATINUM, PALLADIUM, AND RHODIUM}

Health risks from environmental exposure to PGMs have long been considered minimal. However, recent toxicity studies suggest that exposure to these metals can cause asthma, allergies, and other serious health problems $(51,52)$. Most data on Pt toxicity come from chemotherapy studies $(53,54)$, but less is known about $\mathrm{Pd}, \mathrm{Rh}$, and the toxicity and behaviour of particle-bound PGMs emitted from catalytic converters.

As for occupational exposure of workers at catalytic converter plants, Petrucci et al. (55) observed low presence of $\mathrm{Rh}$ and Ir, because these two elements are rarely used in production. The highest reported concentrations were those of Pt in the hair, blood, and urine samples of workers in the final coating and drying sections, and of Pd in those working in the old catalyst recycling section. One study (56) investigated exposure of traffic policemen to $\mathrm{Pt}, \mathrm{Pd}$, and $\mathrm{Rh}$ in the city of Hyderabad, India and verified their levels in policemen's blood and urine. These policemen complained of symptoms such as dermatitis, eye irritation, and respiratory tract problems, which are often associated with toxic metal activity.

In vitro, Migliore et al. (57) reported that Pd salts were less genotoxic than $\mathrm{Pt}$ or $\mathrm{Rh}$ salts, probably because the latter two induce higher oxidative damage.

\section{CONCLUSION}

Mainly due to the widespread use as automotive catalysts for emission control since the 1970s, Pt, Pd, and $\mathrm{Rh}$ have been reported in ever increasing concentrations on airborne particulate matter, which has risen environmental and health concerns. While PGMs emitted from automobile exhausts are primarily deposited locally, long-range atmospheric transport cannot be excluded. Despite increase, however, current environmental PGM levels remain low, and the risks for environment and people are deemed minimal. Even so, currently available data are too scarce to assess the risks. Future studies should take into account that PGMs appear as nanoparticles, which increases their bioavailability, of Pd in particular. Research should also focus on chronic effects at low concentrations.

\section{REFERENCES}

1. Grdenić D. Povijest kemije [History of Chemistry, in Croatian]. Zagreb: Školska knjiga; 2001.

2. Wedepohl KH. The composition of the continental crust. Geochim Cosmochim Acta 1995;59:1217-39. doi: 10.1016/0016-7037(95)00038-2

3. Dubiella-Jackowska A, Polkowska Ż, Namieśnik J. Platinum group elements: a challenge for environmental analytics. Pol J Environ Stud 2007;16:329-45.

4. The National Research Council. Platinum Group Metals: Medical and Biologic Effects of Environmental Pollutants. Washington (DC): National Academy of Sciences; 1977.

5. Cicchella D, De Vivo B, Lima A. Palladium and platinum concentration in soils from the Napoli metropolitan area, Italy: possible effects of catalytic exhausts. Sci Total Environ 2003;308:121-31. doi: 10.1016/S0048-9697(02)00632-0

6. Zereini F, Wiseman C, Püttmann W. Changes in palladium, platinum, and rhodium concentrations, and their spatial distribution in soils along a major highway in Germany from 1994 to 2004. Environ Sci Technol 2007;41:451-6. doi: $10.1021 / \mathrm{es} 061453 \mathrm{~s}$

7. Keith CD, Schreuders T, Cunningham CE. Patent US3441381A - Apparatus for Purifying Exhaust Gases of an Internal Combustion Engine. United States Patent Office, April $29^{\text {th }} 1969$.

8. Nazmul Islam KM, Hildenbrand J, Mosharraf Hossain M. Life cycle impacts of three-way ceramic honeycomb catalytic converter in terms of disability adjusted life year. J Clean Prod 2018;182:600-15. doi: 10.1016/j.jclepro.2018.02.059

9. Suchá V, Mihaljević M, Ettler V, Strnad L. The pH-dependent release of platinum group elements (PGEs) from gasoline and diesel fuel catalysts: Implication for weathering in soils. 
J Environ Manage 2016;171:52-9. doi: 10.1016/j. jenvman.2016.01.034

10. Mitra A, Sen IS. Anthrobiogeochemical platinum, palladium and rhodium cycles of earth: Emerging environmental contamination. Geochim Cosmochim Acta 2017;216:417-32. doi: 10.1016/j.gca.2017.08.025

11. Rai PK. Biomagnetic Monitoring of Particulate Matter in the Indo-Burma Hotspot Region. Amsterdam: Elsevier Science; 2016.

12. Röösli M, Theis G, Künzli N, Staehelin J, Mathys P, Oglesby L, Camenzind M, Braun-Fahrländer C. Temporal and spatial variation of the chemical composition of $\mathrm{PM}_{10}$ at urban and rural sites in the Basel area, Switzerland. Atmos Environ 2001;35:3701-13. doi: 10.1016/S1352-2310(00)00511-2

13. European Environmental Agency (EEA). Every Breath We Take: Improving Air Quality in Europe, Signals 2013. Luxembourg: EEA Publications Office of the European Union; 2013.

14. Fortoul TI, Rodriguez-Lara V, Gonzalez-Villalva A, RojasLemus M, Colin-Barenque L, Bizarro-Nevares P, GarcíaPeláez I, Ustarroz-Cano M, López-Zepeda S, CervantesYépez S, López-Valdez N, Meléndez-García N, EspinosaZurutuza M, Cano-Gutierrez G, Cano-Rodríguez MC. Health Effects of Metals in Particulate Matter, Current Air Quality Issues. InTech 2015. doi: 10.5772/59749

15. Rauch S, Peucker-Ehrenbrink B, Molina LT, Molina MJ, Mos $\mathrm{R}$, Hemond HF. Platinum group elements in airborne particles in Mexico City. Environ Sci Technol 2006;40:7554-60. doi: 10.1021/es061470h

16. Rauch S, Hemond F, Peucker-Ehrenbrink B, Ek KH, Morrison GM. Platinum group element concentrations and osmium isotopic composition in urban airborne particles from Boston, Massachusetts. Environ Sci Technol 2005;39:9464 70 doi: 10.1021/es051310q

17. Leśniewska BA, Godlewska-Żyłkiewicz B, Ruszczyńska A, Bulska E, Hulanicki A. Elimination of interferences in determination of platinum and palladium in environmental samples by inductively coupled plasma mass spectrometry. Anal Chim Acta 2006;564:236-42. doi: 10.1016/j. aca.2006.01.066

18. Godlewska-Żyłkiewicz B, Leśniewska BA, Gasievska U, Hulanicki A. Ion-exchange preconcentration and separation of trace amounts of platinum and palladium. Anal Lett 2000;33:2805-20. doi: 10.1080/00032710008543224

19. Goncalves A, Domínguez JR, Alvarado J. Determination of $\mathrm{Pd}$, Pt and Rh in vehicles escape fumes by GF-AAS and ICP-OES. Talanta 2008;75:523-7. doi: 10.1016/j. talanta.2007.11.055

20. Petrova P, Velichkov S, Velitchkova N, Havezov I, Daskalova N. Problems, possibilities and limitations of inductively coupled plasma atomic emission spectrometry in the determination of platinum, palladium and rhodium in samples with different matrix composition. Spectrochim Acta B 2010;65:130-6. doi: 10.1016/j.sab.2009.12.005

21. Puls C, Limbeck A, Hann S. Bioaccessibility of palladium and platinum in urban aerosol particulates. Atmos Environ 2012;55:213-9. doi: 10.1016/j.atmosenv.2012.03.023

22. Zereini F, Alsenz H, Wiseman CLS, Püttmann W, Reimer E, Schleyer R, Bieber E, Wallasch M. Platinum group elements $(\mathrm{Pt}, \mathrm{Pd}, \mathrm{Rh})$ in airborne particulate matter in rural vs. Urban areas of Germany: Concentrations and spatial patterns of distribution. Sci Total Environ 2012;416:261-8. doi: 10.1016/j.scitotenv.2011.11.070

23. Pan S, Zhang G, Suna Y, Chakraborty P. Accumulating characteristics of platinum group elements (PGE) in urban environments, China. Sci Total Environ 2009;407:4248-52. doi: 10.1016/j.scitotenv.2009.03.030

24. Jackson MT, Prichard HM, Sampson J. Platinum-group elements in sewage sludge and incinerator ash in the United Kingdom: Assessment of PGE sources and mobility in cities. Sci Total Environ 2010;408:1276-85. doi :10.1016/j. scitotenv.2009.09.014

25. Spada TTN, Bozlaker A, Chellam S. Multi-elemental characterization of tunnel and road dusts in Houston, Texas using dynamic reaction cell-quadrupole-inductively coupled plasma-mass spectrometry: Evidence for the release of platinum group and anthropogenic metals from motor vehicles. Anal Chim Acta 2012;735:1-8. doi: 10.1016/j. aca.2012.05.026

26. Hsu W-H, Jiang S-J, Sahayam AC. Determination of Pd, Rh, $\mathrm{Pt}, \mathrm{Au}$ in road dust by electrothermal vaporization inductively coupled plasma mass spectrometry with slurry sampling. Anal Chim Acta 2013;794:15-9. doi: 1016/j.aca.2013.08.001

27. Hays MD, Cho S-H, Baldauf R, Schauer JJ, Shafer M. Particle size distributions of metal and non-metal elements in an urban near-highway environment. Atmos Environ 2011;45:925-34. doi: 10.1016/j.atmosenv.2010.11.010

28. Rinkovec J, Pehnec G, Žužul S, Rončević S. Determination of platinum group elements in particulate matter by inductively coupled plasma mass spectrometry. Bull Environ Contam Toxicol 2017;98:672-6. doi: 10.1007/s00128-0172061-2

29. Zhang L, Wang Y, Liu Y, Li Z, Li X. Variation of platinum group elements (PGE) in airborne particulate matter $\left(\mathrm{PM}_{2.5}\right)$ in the Beijing urban area, China: A case study of the 2014 APEC summit. Atmos Environ 2018;198:70-6. doi: 10.1016/j.atmosenv.2018.10.044

30. Morton-Bermea O, Amador-Muñoz O, Martínez-Trejo L, Hernández-Álvarez E, Beramendi-Orosco L, García-Arreola ME. Platinum in $\mathrm{PM}_{2.5}$ of the metropolitan area of Mexico City. Environ Geochem Health 2014;36:987-94. doi: 10.1007/s10653-014-9613-8

31. Sen IS, Mitra A, Peucker-Ehrenbrink B, Rothenberg SE, Nand Tripathi S, Bizimis M. Emerging airborne contaminants in India: Platinum Group Elements from catalytic converters in motor vehicles. Appl Geochem 2016;75:100-6. doi: 10.1016/j.apgeochem.2016.10.006

32. Rinkovec J, Pehnec G, Godec R, Davila S, Bešlić I. Spatial and temporal distribution of platinum, palladium and rhodium in Zagreb air. Sci Total Environ 2018;636:456-63 doi: 10.1016/j.scitotenv.2018.04.295

33. Liu Y, Fua B, Shenb Y, Yub Y, Liu H, Zhaoa Z, Zhangd L. Seasonal properties on $\mathrm{PM}_{1}$ and PGEs $(\mathrm{Rh}, \mathrm{Pd}$, and $\mathrm{Pt})$ in $\mathrm{PM}_{1}$. Atmos Pollut Res 2018;9:1032-7. doi: 10.1016/j. apr.2018.03.009

34. Barbante C, Veysseyre A, Ferrari C, Van de Velde K, Morel C, Capodoglio G. Greenland snow evidence of large scale atmospheric contamination for platinum, palladium and rhodium. Environ Sci Technol 2001;35:835-9. doi: 10.1021/ es000146y

35. Jutze GA, Foster KE. Recommended standard method for atmospheric sampling of fine particulate matter by filter 
media-high-volume sampler. J Air Pollut Control Assoc 1967; 17:17-25, doi: 10.1080/00022470.1967.10468936

36. Wanjura JD, Parnell CB Jr., Shaw BW, Lacey RE. Design and evaluation of a low-volume total suspended particulate sampler. Transact ASAE 2005;48:1547-52. doi: 10.13031/2013.19186

37. Gómez B, Palacios MA, Gómez M, Sanchez JL, Morrison G, Rauch S, McLeod C, Ma R, Caroli S, Alimonti A, Petrucci E, Bocca B, Schramel P, Zischka M, Petterson C, Wass U. Levels and risk assessment for humans and ecosystems of platinum-group elements in the airborne particles and road dust of some European cities. Sci Total Environ 2002:299:119. doi: 10.1016/S0048-9697(02)00038-4

38. Simpson LA, Thomsen M, Alloway BJ, Parker A. A dynamic reaction cell (DRC) solution to oxide-based interferences in inductively coupled plasma mass spectrometry (ICP-MS) analysis of the noble metals. J Anal At Spectrom 2001;16:1375-80. doi: 10.1039/b107818f

39. Alsenz H, Zereini F, Wiseman CLS, Püttmann W. Analysis of palladium concentrations in airborne particulate matter with reductive co-precipitation, He collision gas and ID-ICPQ-MS. Anal Bioanal Chem 2009;395:1919-27. doi: 10.1007/ s00216-009-3143-8

40. Bozlaker A, Spada NJ, Fraser MP, Chellam S. Elemental characterization of $\mathrm{PM}_{25}$ and $\mathrm{PM}_{10}$ emitted from light duty vehicles in the washburn tunnel of Houston, Texas: release of rhodium, palladium, and platinum. Environ Sci Technol 2014;48:54-62. doi: 10.1021/es4031003

41. Rauch S, Lu M, Morrison GM. Heterogeneity of platinum group metals in airborne particles. Environ Sci Technol 2001;35:595-9. doi: 10.1021/es000048c

42. Petrucci F, Bocca B, Alimonti A, Caroli S. Determination of $\mathrm{Pd}, \mathrm{Pt}$ and $\mathrm{Rh}$ in airborne particulate and road dust by highresolution ICP-MS: a preliminary investigation of the emission from automotive catalysts in the urban area of Rome. J Anal At Spectrom 2000;15:525-8. doi: 10.1039/ a909792i

43. Bocca B, Caimi S, Smichowski P, Gómez D, Caroli S. Monitoring $\mathrm{Pt}$ and $\mathrm{Rh}$ in urban aerosols from Buenos Aires, Argentina. Sci Total Environ 2006;358:255-64. doi: 10.1016/j.scitotenv.2005.04.010

44. Zereini F, Wiseman C, Alt F, Messerschmidt J, Müller J, Urban H. Platinum and rhodium concentrations in airborne particulate matter in Germany from 1988 to 1998. Environ Sci Technol 2001;35:1996-2000. doi: 10.1021/es001126z

45. Zereini F, Alt F, Messerschmidt J, von Bohlen A, Liebl K, Puttmann W. Concentration and distribution of platinum group elemnts $(\mathrm{Pt}, \mathrm{Pd}, \mathrm{Rh})$ in airborne particulate matter in Frankfurt am Main, Germany. Environ Sci Technol 2004;38:1686-92. doi: 10.1016/j.scitotenv.2011.11.070

46. Diong HT, Das R, Khezri B, Srivastava B, Wang X, Sikdar $\mathrm{PK}$, Webster RD. Anthropogenic platinum group element
(Pt, $\mathrm{Pd}, \mathrm{Rh}$ ) concentrations in $\mathrm{PM}_{10}$ and $\mathrm{PM}_{2.5}$ from Kolkata, India. SpringerPlus 2016;5:1242. doi: 10.1186/s40064-0162854-5

47. Ertl G, Knözinger H, Weitkamp J. Environmental Catalysis. Weinheim: Wiley VCH; 1996.

48. Sen IS. Platinum group element pollution is a growing concern in countries with developing economy. Environ Sci Technol 2013;47:13903-4. doi: 10.1021/es404890e

49. Zereini F, Wiseman CLS, Püttmann W. In vitro investigations of platinum, palladium, and rhodium mobility in urban airborne particulate matter $\left(\mathrm{PM}_{10}, \mathrm{PM}_{2.5}\right.$ and $\left.\mathrm{PM}_{1}\right)$ using simulated lung fluids. Environ Sci Technol 2012;46:1032633. doi: 10.1021/es3020887

50. Wiseman CLS, Niu J, Levesque C, Chénier M, Rasmussen PE. An assessment of the inhalation bioaccessbility of platinum group elements in road dust using a simulated lung fluid. Environ Pollut 2018;241:1009-17. doi: 10.1016/j. envpol.2018.06.043

51. Schierl R. Ochmann U. Occupational health aspects of platinum. In: Zereini F, Wiseman C, editors. Platinum Metals in the Environment. Berlin, Heidelberg: Springer-Verlag, 2015. p. 463-76. doi: 10.1007/978-3-662-44559-4

52. Wiseman CLS. Platinum metals in airborne particulate matter and their bioaccessibility. In: Zereini F, Wiseman C, editors. Platinum Metals in the Environment. Berlin, Heidelberg: Springer-Verlag, 2015. p. 447-62. doi: 10.1007/978-3-66244559-4

53. Perez-Ramirez C, Canadas-Garre M, Alnatsha A, Villar E, Delgado JR, Faus-Dader MJ, Calleja-Hernandez MA. Pharmacogenic predictors of toxicity to platinum based chemotherapy in non-small cell lung cancer patients. Pharmacol Res 2016;111:877-84. doi: 10.1016/j. phrs.2016.08.002

54. Lazarević T, Rilak A, Bugarčić ŽD. Platinum palladium, gold and ruthenium complexes as anticancer agents. Eur J Med Chem 2017;142:8-31. doi: 10.1016/j.ejmech.2017.04.007

55. Petrucci F, Violante N, Senofonte O, Cristaudo A, Di Gregorio M, Forte G, Alimonti A. Biomonitoring of a worker population exposed to platinum dust in a catalyst production plant. Occup Environ Med 2005;62:27-33. doi: 10.1136/ oem.2004.016022

56. Kamala CT, Balaram V, Satyanarayanan M, Kiran Kumar A, Subramanyam KSV. Biomonitoring of airborne platinum group elements in urban traffic police officers. Arch Environ Contam Toxicol 2015;68:421-31. doi: 10.1007/s00244-0140114-7

57. Migliore L, Frenzilli G, Nesti C, Fortaner S, Sabbioni E. Cytogenetic and oxidative damage induced in human lymphocytes by platinum, rhodium and palladium compounds. Mutagenesis 2002;17:411-7. doi: 10.1093/ mutage/17.5.411 


\section{Platina, paladij i rodij u lebdećim česticama u zraku}

Mjerljive količine platine, paladija i rodija, čak i u udaljenim područjima našega planeta, dokaz su globalne prirode problema. Katalitički pretvarači suvremenih vozila, uz neke druge primjene (npr. proizvodnja nakita, kemijska industrija, lijekovi protiv raka), smatraju se glavnim izvorom kontaminacije metalima platinske skupine (PGM). Poznato je da količina PGM-ova koja se emitira iz automobilskih katalizatora varira ovisno o tipu, starosti i stanju motora i katalizatora te o brzini i uvjetima vožnje. Pregled postojeće literature pokazuje da se koncentracija tih metala značajno povećala u posljednjih dvadeset godina, osobito paladija, jer se pokazao učinkovitijim katalizatorom od platine. Još se raspravlja jesu li, i u kojoj mjeri, emitirane količine PGM toksične za ljude. Potencijalni rizik za zdravlje zbog izloženosti tim elementima treba uzeti u obzir za one koji žive u urbanim sredinama s prometnim cestama ili duž glavnih autocesta. Zbog važnosti PGM-ova i njihovih razina u lebdećim česticama, za pouzdano određivanje potrebne su osjetljive metode. Raspravljalo se o specifičnim koracima analitičkih postupaka za kvantifikaciju PGM-ova u lebdećim česticama. Opisane su i najčešće korištene metode priprave, kao i metode detekcije i određivanja PGM-ova.

KLJUČNE RIJEČI: ICP-MS, katalitički pretvornik, mikrovalna razgradnja, platinska skupina metala, spektralne interferencije 